\title{
Surface elevation and mass changes of all Swiss glaciers 1980-2010
}

\author{
M. Fischer ${ }^{1}$, M. Huss ${ }^{1,2}$, and M. Hoelzle ${ }^{1}$ \\ ${ }^{1}$ Department of Geosciences, University of Fribourg, 1700 Fribourg, Switzerland \\ ${ }^{2}$ Laboratory of Hydraulics, Hydrology and Glaciology (VAW), ETH Zurich, 8093 Zurich, Switzerland
}

Correspondence to: M. Fischer (mauro.fischer@unifr.ch)

Received: 14 August 2014 - Published in The Cryosphere Discuss.: 29 August 2014

Revised: 23 February 2015 - Accepted: 24 February 2015 - Published: 17 March 2015

\begin{abstract}
Since the mid-1980s, glaciers in the European Alps have shown widespread and accelerating mass losses. This article presents glacier-specific changes in surface elevation, volume and mass balance for all glaciers in the Swiss Alps from 1980 to 2010. Together with glacier outlines from the 1973 inventory, the DHM25 Level 1 digital elevation models (DEMs) for which the source data over glacierized areas were acquired from 1961 to 1991 are compared to the swissALTI $^{3 \mathrm{D}}$ DEMs from 2008 to 2011 combined with the new Swiss Glacier Inventory SGI2010. Due to the significant differences in acquisition dates of the source data used, mass changes are temporally homogenized to directly compare individual glaciers or glacierized catchments. Along with an in-depth accuracy assessment, results are validated against volume changes from independent photogrammetrically derived DEMs of single glaciers. Observed volume changes are largest between 2700 and $2800 \mathrm{~m}$ a.s.l. and remarkable even above $3500 \mathrm{~m}$ a.s.l. The mean geodetic mass balance is $-0.62 \pm 0.07 \mathrm{~m}$ w.e. $\mathrm{yr}^{-1}$ for the entire Swiss Alps over the reference period 1980-2010. For the main hydrological catchments, it ranges from -0.52 to $-1.07 \mathrm{~m}$ w.e. $\mathrm{yr}^{-1}$. The overall volume loss calculated from the DEM differencing is $-22.51 \pm 1.76 \mathrm{~km}^{3}$.
\end{abstract}

\section{Introduction}

Fluctuations of mountain glaciers are known as a sensitive indicator for climatic changes (e.g. IPCC, 2013). Recent atmospheric warming has caused increased mass loss of glaciers all over the world (e.g. Zemp et al., 2009; Radić and Hock, 2014), which significantly contributes to present sea-level rise (e.g. Marzeion et al., 2012; Gardner et al., 2013) and affects the runoff regimes of glacierized catchments in differ- ent regions around the globe (e.g. Kaser et al., 2010; Huss, 2011; Sorg et al., 2012).

Glaciers of the European Alps showed general mass loss and shrinkage since the Little Ice Age maximum around 1850 (Zemp et al., 2008), despite intermittent phases of positive mass and area changes around 1890, during the 1910s and from the late 1970s to the mid-1980s (Glaciological Reports, 1960-2015). Since then, pronounced glacier retreat has been reported again (Paul et al., 2011; Huss, 2012). Glacier area changes are documented by the comparison of consecutive inventories (e.g. Lambrecht and Kuhn, 2007; Diolaiuti et al., 2012; Fischer et al., 2014; Gardent et al., 2014). Mass balance data are available either from annual field measurements on individual glaciers using the direct glaciological method (e.g. WGMS, 2012) or from the comparison of the glacier surface topography of different years and a density assumption for converting volume to mass change (e.g. Abermann et al., 2009; Carturan et al., 2013a). Together with the increasing number of digital elevation models (DEMs) available worldwide and the fact that inaccessible areas and entire glacier systems can be measured, this so-called geodetic method has become a popular approach to derive surface elevation and mass changes for a large number of glaciers (e.g. Rignot et al., 2003; Larsen et al., 2007; Bolch et al., 2008; Berthier et al., 2010; Nuth et al., 2010; Gardelle et al., 2012a).

Paul and Haeberli (2008) analyzed the spatial variability of glacier elevation changes in the Swiss Alps between 1985 and 1999 by comparing the DHM25 Level 1 DEMs ( $25 \mathrm{~m}$ resolution) created from topographic maps by the Swiss Federal Office of Topography (swisstopo) with the medium-resolution $(90 \mathrm{~m})$ Shuttle Radar Topography Mission (SRTM) DEM. Several factors that might have an important influence on the accuracy of glacier elevation changes 
derived from DEM differencing have, however, not been conclusively assessed in their study: differences in the reference years of the surface elevation information used for individual regions, the problem of radar penetration into snow and ice (Dall et al., 2001; Gardelle et al., 2012b) and/or impacts of downscaling DEMs to higher resolution (Gardelle et al., 2012b; Carturan et al., 2013a). Furthermore, applying the medium-resolution SRTM DEM to high-mountain areas is problematic due to the systematic biases reported for high elevations (Berthier et al., 2006). Numerically, these regions are generally dominated by very small glaciers, hereafter defined as being smaller than $0.5 \mathrm{~km}^{2}$. Abermann et al. (2010) and Fischer et al. (2014) show that use of the most accurate and highest resolution source data available is of particular importance for change assessments of these smallest glacier size classes.

Due to the recent compilation of more detailed source data, we are able to present an extended re-evaluation of glacierspecific changes in surface elevation, volume and geodetic mass balance for every single glacier in Switzerland. We compare the DHM25 Level 1 DEMs dating from between 1961 and 1991 over glacierized areas with the swissALTI ${ }^{3 D}$ DEMs from 2008-2011, and we combine the former with the 1973 inventory (Müller et al., 1976) and the latter with the new Swiss Glacier Inventory SGI2010 (Fischer et al., 2014). For direct comparison between individual glaciers or glacierized catchments, we temporally homogenize resulting mass changes to a consistent period, 1980-2010. This is necessary due to significant differences in the acquisition dates of the source data. We discuss various sources of possible error, perform an in-depth accuracy assessment of our results and validate them using independent volume changes from photogrammetrically derived DEMs. Furthermore, we comment on the controlling factors and the spatial variability of observed glacier mass changes.

\section{Study region and data sets}

\subsection{Study region}

The study area covers the entire Swiss Alps, where glaciers have generally shown rapid mass loss after a short period of mass gain between the late 1970s and the mid-1980s (Huss et al., 2010a). Overall, small, thin and rather steep glaciers dominate. Almost $90 \%$ of all glaciers were smaller than $1.0 \mathrm{~km}^{2}$ in 2010 . At that time, the total glacierized area was $944.3 \pm 24.1 \mathrm{~km}^{2}$, corresponding to an area change of $-362.6 \mathrm{~km}^{2}\left(-27.7\right.$ or $-0.75 \% \mathrm{yr}^{-1}$ ) since 1973 (Fischer et al., 2014). If we apply the approach of Huss and Farinotti (2012) to all Swiss glaciers, the average estimated mean glacier thickness was $63 \mathrm{~m}$ in 2010 , and $92 \%$ of the estimated total glacier volume of $59.9 \mathrm{~km}^{3}$ was stored within only $10 \%$ of the 1420 glaciers comprised in the SGI2010.

\subsection{Digital elevation models and glacier outlines}

The initial glacier surface topography at the beginning of the observation period (hereafter referred to as $t_{1}$ ) is given by the DHM25 Level 1 DEMs from swisstopo, for which digitized contour lines and spot heights from the Swiss national topographic maps 1:25000 were interpolated to a regular grid with $25 \mathrm{~m}$ spacing. The positional accuracy is reported to range between 2.5 and $7.5 \mathrm{~m}$. The vertical accuracy was estimated by comparison of known spot heights on stable terrain with corresponding cell values of the DHM25 Level 1 DEMs and ranges between 3.7 and $8.2 \mathrm{~m}$ on average for rugged high-mountain topography depending on individual map sheets (Rickenbacher, 1999; swisstopo, 2000). Because spot heights are typically located at topographical extreme points like hilltops or depressions, the actual vertical accuracy over "average terrain" such as glacier surface topography is probably considerably higher. For glacierized areas, the dating of contour lines used for the creation of the DHM25 Level 1 DEMs is not consistent with corresponding specifications given in the product information (swisstopo, 2000). Therefore, we manually reconstructed the individual reference years of the surface topography at $t_{1}$ for every glacier by comparison of the DHM25 Level 1 contour lines with those from repeated updates of the $1: 25000$ topographic maps with known reference years (cf. "journey through time" maps available through map.geo.admin.ch). In addition to the obvious regional differences in $t_{1}$, there is a certain trend towards earlier $t_{1}$ for small glaciers, for which surface contour lines were less frequently updated (Fig. 1).

Recent glacier surface topography, i.e. at the end of the observation period (hereafter referred to as $t_{2}$ ), is provided by the new $2 \mathrm{~m}$ resolution swissALTI ${ }^{3 \mathrm{D}}$ DEMs. For areas above $2000 \mathrm{~m}$ a.s.l., these were created by stereocorrelation of high-resolution $(25 \mathrm{~cm})$ 2008-2011 SWISSIMAGE Level 2 aerial orthophotographs. For these areas, the vertical accuracy is \pm 1 to $3 \mathrm{~m}$ on average. For areas below $2000 \mathrm{~m}$ a.s.l., the swissALTI ${ }^{3 \mathrm{D}}$ DEMs are more accurate $( \pm 0.5 \mathrm{~m}$ at the $1 \sigma$ level) since they were created using airborne laser scanning data (swisstopo, 2013).

The surface area of individual glaciers at $t_{1}$ is derived from the finalized digital version of the Swiss Glacier Inventory 1973 (SGI1973; Maisch et al., 2000; Paul, 2004), which was originally compiled by Müller et al. (1976) from stereophotogrammetry-based interpretation of aerial photographs acquired in early September 1973. The considerable time difference between the acquisition of the SGI1973 source data and individual DHM25 Level 1 DEMs used for $t_{1}$ (Fig. 1) is acceptable as only small area changes and an almost balanced mass budget of glaciers were reported for the European Alps between 1960 and the mid-1980s (Glaciological Reports, 1960-2015; Paul et al., 2004; Huss, 2012). For $t_{2}$, the glacier outlines originate from the latest Swiss Glacier Inventory SGI2010 derived by manual digitization from high-resolution $(25 \mathrm{~cm})$ aerial orthophotographs ac- 


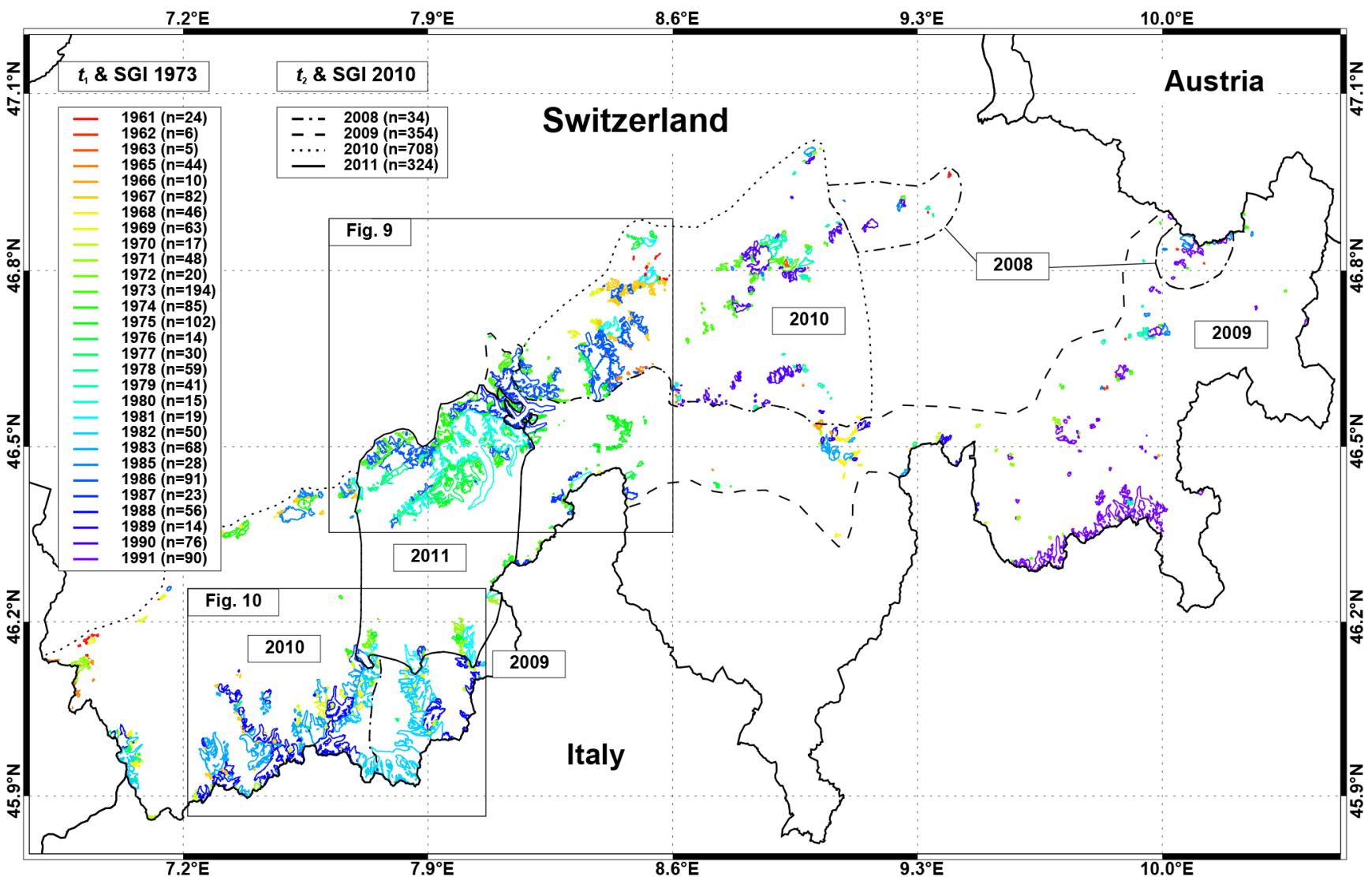

Figure 1. Glaciers in the Swiss Alps. Colours refer to the acquisition date of the elevation information (DHM25 Level 1) defining the beginning of the investigated period $\left(t_{1}\right)$. Black lines delimit areas of equal acquisition dates of both glacier outlines and surface topography at the end of the investigated period $\left(t_{2}\right)$. Two black rectangles show the perimeters of close-ups with resulting mean geodetic mass balance.

quired between 2008 and 2011 (Fischer et al., 2014). Applying the SGI2010 and the swissALTI ${ }^{3 \mathrm{D}}$ DEMs as source data for $t_{2}$ is ideal because their acquisition dates are mostly identical for individual glaciers.

\subsection{Validation data}

Time series of surface mass balance for glaciers of different type and size class covering the entire Swiss Alps over the last few decades (Huss et al., 2010a, b) are used to validate the geodetic mass balances presented here. These series rely on ice volume changes derived from high-accuracy photogrammetrical DEMs for sub-decadal to multi-decadal time intervals (Bauder et al., 2007). By using a distributed mass balance modelling approach including comprehensive field data sets (winter accumulation, summer ablation and discharge measurements), annual mass balance series were calculated that agree with the observed geodetic mass changes.

\section{Methods}

\subsection{Calculation of glacier volume change and average mass balance}

Prior to the calculation of surface elevation changes, the swissALTI ${ }^{3 \mathrm{D}}$ DEMs were resampled to a grid cell size of $25 \mathrm{~m}$ (i.e. equal to the resolution of the DHM25 Level 1 DEMs). Because glacier polygons of the SGI2010 were coded and named according to the 1973 outlines they fell into or overlapped with (Fischer et al., 2014), elevation changes could be calculated for individual glacier entities as a next step by subtracting the DHM25 Level 1 DEMs from the swissALTI ${ }^{3 \mathrm{D}}$ DEMs (Fig. 2).

The glacier-individual total volume change $\Delta V\left(\mathrm{~m}^{3}\right)$ for the respective survey period was calculated as follows:

$$
\Delta V=\overline{\Delta z} \cdot A_{1973}
$$

where $\overline{\Delta z}(\mathrm{~m})$ is the average elevation change calculated from the difference between the swissALTI ${ }^{3 \mathrm{D}}$ and the DHM25 Level 1 DEMs within the perimeter covered by the 


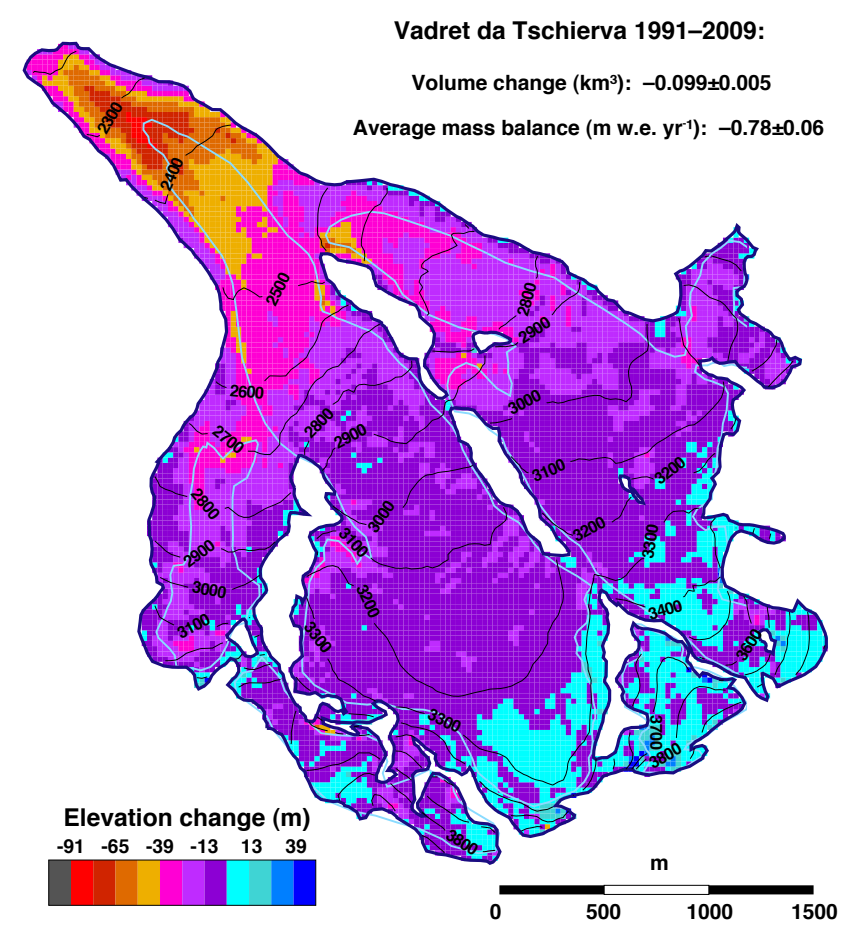

Figure 2. Spatial distribution of elevation changes for Vadret da Tschierva 1991-2009 within the digital glacier outlines from both the 1973 (dark blue) and the 2010 (light blue) inventories.

glacier in $1973\left(A_{1973}\left(\mathrm{~m}^{2}\right)\right)$. Then the area-averaged specific geodetic mass balance rate $\left(\mathrm{m}\right.$ w.e. $\left.\mathrm{yr}^{-1}\right)$ was calculated with

$\dot{B}=\frac{\Delta V \cdot f_{\Delta V}}{\bar{A} \cdot \Delta t}$,

where $f_{\Delta V}$ is a conversion factor (without unit) used to transform $\Delta V$ into a mass change, $\bar{A}\left(\mathrm{~m}^{2}\right)$ the average area between 1973 and 2010 calculated as $\left(A_{1973}+A_{2010}\right) / 2$ and $\Delta t$ the length of the observation period $\left(t_{2}-t_{1}\right)$ in years. We hereafter refer to the area-averaged specific geodetic mass balance rate as "average mass balance". The conversion factor $f_{\Delta V}$ might vary from glacier to glacier depending on the length of the observation period, the respective mass balance and the firn compaction history. Due to the fairly long observation periods, $f_{\Delta V}$ is set as a constant of 0.85 corresponding to a density of volume change of $850 \pm 60 \mathrm{~kg} \mathrm{~m}^{-3}$ (Huss, 2013), which is consistent with other studies (Sapiano et al., 1998; Fischer, 2011; Zemp et al., 2013).

The significant regional differences in the length of the observation period (Fig. 1) imply that glacier-individual average mass balances $\dot{B}_{g}$ derived from the DEM differencing can not be directly compared to each other. In order to homogenize the glacier-individual observation periods to one comparable time interval, we make use of the data set of Huss (2012) that provides annual mass balance variability extrapolated to the entire European Alps based on a combination

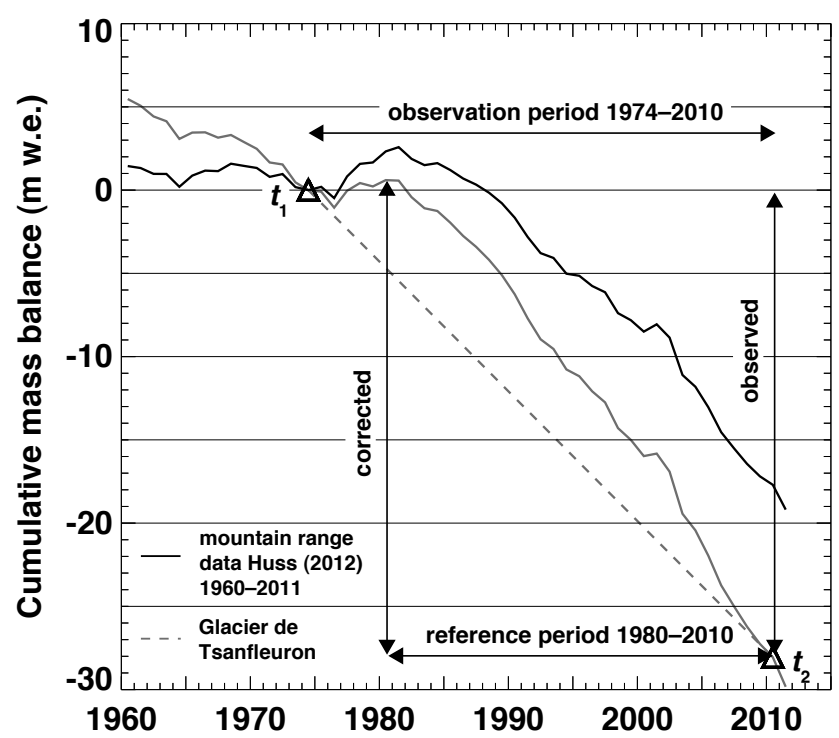

Figure 3. Temporal homogenization of cumulative average mass balance from DEM differencing for Glacier de Tsanfleuron (dark grey) based on cumulative mean annual mountain-range mass balance from Huss (2012).

of all available mass balance data covering our period of interest. The deviation of average mass balance $\dot{B}_{g}$ for glacier $g$ (dashed grey line in Fig. 3) from the mountain-range mean (black line in Fig. 3) over the respective observation period $\overline{B_{t_{2}-t_{1}}}$ is used as a scaling factor to account for the variability in glacier-wide mass balance (Kuhn et al., 1985). The mean mountain-range mass balance from Huss (2012) for an individual year $i, B_{i, \mathrm{mr}}$, accounts for the temporal mass balance variability. The annual mass balance $B_{i, g}$ for year $i$ and every glacier $g$ is thus calculated with

$B_{i, g}=B_{i, \mathrm{mr}}+\dot{B}_{g}-\overline{B_{t_{2}-t_{1}}}$.

Because 2010 is the reference year $t_{2}$ for most of the investigated glacier entities and the mean observation period is $\approx 30$ years (Fig. 1), the hydrological years 1980/81-2009/10 are defined as the reference observation period over the entire Swiss Alps over which annual mass balances for individual glaciers $B_{i, g}$ are cumulated (grey line in Fig. 3). Using this approach, mass changes are temporally homogenized and can be compared and further analyzed.

\subsection{Analysis of controls}

Averaged over representative samples (number of glaciers) and observation periods (number of years), glacier area and elevation changes are usually in agreement with changes in air temperature and precipitation recorded over the investigated areas and time intervals (e.g. Abermann et al., 2009; VanLooy and Forster, 2011; Carturan et al., 2013a). Within a mountain range and despite similar climatic changes, the 
differences in long-term mass balance can, however, be significant between individual - and even adjacent - glaciers (e.g. Kuhn et al., 1985; Vincent, 2002; Larsen et al., 2007; Abermann et al., 2011). Different factors have been identified which can explain this variability to a certain extent. For instance, the glacier hypsometry, i.e. the distribution of glacier area and volume with altitude, plays an important role (Furbish and Andrews, 1984; Benn and Evans, 2010). Also, the characteristic glacier response time and dynamic adjustment to a certain climatic forcing varies with glacier size and affects the specific mass balance (Jóhannesson et al., 1989; Huss et al., 2012). Larger (and more gently sloping) glaciers are expected to lag behind the current climatic forcing and to show more negative mass balances than smaller (and steeper) glaciers (Hoelzle et al., 2003). Very small glaciers situated in cirques, niches and below headwalls generally react faster to climatic changes (Kuhn, 1995), but their individual response to the latter is - in relative terms - even more variable than for larger glaciers (Carturan et al., 2013b). Furthermore, local topographic and microclimatic factors are important for the behaviour and dynamics of mountain glaciers in general (e.g. Benn and Lehmkuhl, 2000; Oerlemans, 2010) and for very small glaciers in particular (e.g. DeBeer and Sharp, 2009; Hughes, 2009). These factors can be parameterized with geometrical indices which are related to the observed variability in long-term mass changes (Huss et al., 2012).

In order to identify the controlling factors and to better understand the spatial variability of the observed surface elevation and mass changes, a correlation analysis between the average mass balance over the reference period 1980-2010 and classes of (1) mean area, (2) median elevation, (3) surface slope of the glacier terminus and (4) dominant aspect, hereafter referred to as mean aspect, was performed. Huss (2012) showed that these four geometrical indices can explain some of the variability in observed long-term mass balances. For the surface slope of the glacier terminus, the testing of different values indicated that the average surface slope over the lowermost $25 \%$ of the glacier at $t_{1}$ resulted in the highest correlation. For mean aspect, the initially eight classes were rearranged into five classes of equivalent potential clear-sky radiation (N, NW/NE, W/E, SW/SE, S) prior to the correlation analysis.

\section{Accuracy assessment and validation}

\subsection{Quality of input DEMs over selected glaciers}

Photogrammetrically derived DEMs of the same acquisition dates as the DHM25 Level 1 DEMs for $t_{1}$ and the swissALTI ${ }^{3 \mathrm{D}}$ DEMs for $t_{2}$ are available for 13 glaciers covering $207.3 \mathrm{~km}^{2}$ (15.9\% of the total glacierized surface area) in 1973 and 12 glaciers covering $88.2 \mathrm{~km}^{2}(9.3 \%)$ in 2010 (Bauder et al., 2007, updated). Statistical comparisons of these DEMs show that for glacierized surface topography, the actual vertical accuracies of both the DHM25 Level 1 and the swissALTI ${ }^{3 \mathrm{D}}$ DEMs are likely much better in the glacier-wide mean than assumed by the average error values taken from literature. Both mean $(\mu=-1.19 \mathrm{~m})$ and median $(\widetilde{x}=-1.36 \mathrm{~m})$ elevation differences are slightly negative when subtracting the DHM25 Level 1 DEMs from the photogrammetrical DEMs at $t_{1}$. For the swissALTI ${ }^{3 \mathrm{D}}$ DEMs at $t_{2}$, mean $(\mu=0.50 \mathrm{~m})$ and median $(\widetilde{x}=0.21 \mathrm{~m})$ elevation differences are slightly positive and show even closer match with the photogrammetrical DEMs. The standard deviations ( $1 \sigma$ level) and interquartile ranges of the elevation differences are comparable for both the DHM25 Level 1 DEMs and the swissALTI ${ }^{3 \mathrm{D}}$ DEMs. Hence, the uncertainties in glacier surface elevation are probably very similar for individual grid cells both at $t_{1}$ and $t_{2}$ (Fig. 4).

\subsection{DEM comparison over stable terrain}

An analysis of possible elevation-, slope- and aspectdependent biases in DEM differencing is carried out by comparing the DHM25 Level 1 DEMs with the swissALTI ${ }^{3 \mathrm{D}}$ DEMs over stable terrain. The spatial distribution of surface elevation changes outside the glaciers is calculated within a mask around every entity (Fig. 5a) and over about twice the area glacierized at $t_{1}$. The mean offset between both DEMs, which we do not correct for, is $-1.47 \pm 6.82$ $(1 \sigma) \mathrm{m}$ (Fig. 5b). Thus, on average, the DHM25 Level 1 DEMs are slightly higher over stable terrain than the recent swissALTI ${ }^{3 \mathrm{D}}$ DEMs. The mean standard deviation over all stable terrain close to glacierized areas of $\pm 6.82 \mathrm{~m}$ agrees with the nominal uncertainty, $\sigma_{\Delta z}$, assessed with literaturebased uncertainty estimates (Rickenbacher, 1999; swisstopo, 2000).

We find an almost linear but comparatively moderate increase of the elevation difference between both input DEMs with elevation $(0.03 \mathrm{~m}$ between 1300 and $2000 \mathrm{~m}$ a.s.l. to $-2.13 \mathrm{~m}$ above $3500 \mathrm{~m}$ a.s.l. on average) (Fig. 5c). Together with the scatter of the bias, which also increases towards higher elevations, this is probably due to the general occurrence of more rugged and steeper terrain with increasing elevation. No dependency is found when relating the mean offset to classes of slope. However, the scatter significantly increases towards steep slopes. The bias is slightly dependent on aspect. While areas with a mean aspect NE and SW show the same mean offset as the overall value, positive values result for pixels with a mean aspect W-NW-N and negative values for pixels facing E-SE-S, i.e. exposed to the opposite direction (Fig. 5a). This points to a slight horizontal shift in the NW-SE direction of the elevation information included in both input DEMs. We assume this shift to originate from the creation of the DHM25 Level 1 source data and therefore calculate the influence of its correction via coregistration according to Nuth and Kääb (2011) for the 45 largest glaciers spread over the entire Swiss Alps with a surface area of $650 \mathrm{~km}^{2}$ at $t_{1}$. The effect of this correction on 


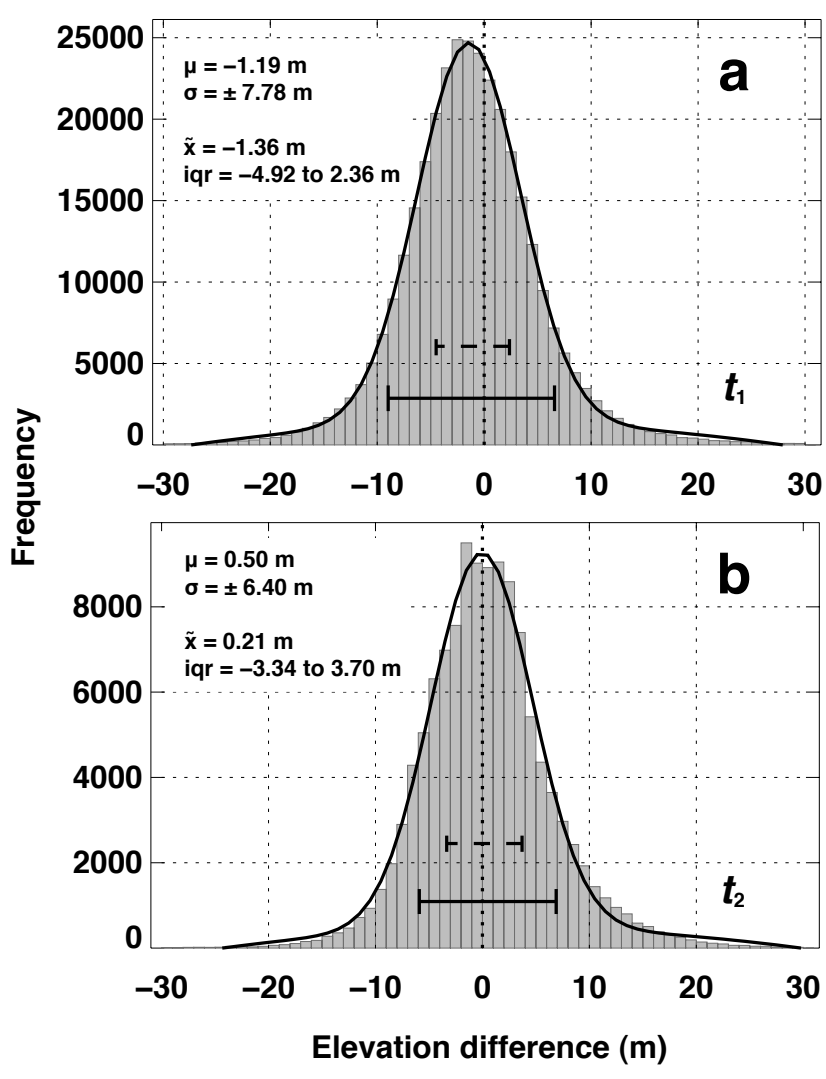

Figure 4. Distribution of (a) DHM25 Level 1 minus photogrammetrical DEM differences at $t_{1}$ and (b) swissALTI ${ }^{3 \mathrm{D}}$ minus photogrammetrical DEM differences at $t_{2}$ over selected glaciers with available independent, photogrammetrically derived DEMs. The black curves are normal fits over the data, the solid bars mark the standard deviation at the $1 \sigma$ level and the dashed bars the interquartile range (iqr). In addition, the mean $(\mu)$ and median $(\widetilde{x})$ elevation differences are given.

the average mass balance of individual glaciers turns out to be on the order of $\pm 10^{-4}$ to $10^{-2} \mathrm{~m}$ w.e. $\mathrm{yr}^{-1}$. Therefore, we consider the impact of the detected DEM shifts on calculated surface elevation, volume and mass changes as negligible for the entire Swiss Alps and do not co-register the source DEMs prior to differencing.

\subsection{Uncertainty}

Two "extreme approaches" have been applied in literature to assess the uncertainty in glacier volume changes derived by DEM differencing. For individual grid cells, the uncertainty in surface elevation changes is either assumed to be totally correlated or totally uncorrelated in space. In the former case, the uncertainty in the glacier-individual volume change is given by the standard deviation of measured point elevation errors (e.g. Cox and March, 2004; Larsen et al., 2007). In the latter case, errors are considered as totally uncorrelated (totally random) in space (e.g. Thibert et al., 2008), and the uncertainty is smaller by a factor of $\sqrt{n}$ compared to totally correlated errors, where $n$ is the number of grid cells over which the DEM differencing is carried out. By determining the spatial correlation lengths of elevation differences from the comparison of input DEMs over stable terrain, Rolstad et al. (2009) recommended a compromise between these two extreme approaches. Motyka et al. (2010) and Trüssel et al. (2013), for instance, also applied this third approach and showed that the degree of the spatial correlation of DEM errors influences the overall uncertainty in geodetic volume and mass changes.

The uncertainty in surface elevation, volume and mass changes presented in this study is mainly given by the uncertainty related to the two DEMs used. Hereafter, a simple implementation of Rolstad et al. (2009) is applied to estimate the uncertainty in the glacier-individual average elevation change $\sigma_{\Delta z, g}(\mathrm{~m})$. This approach does not account for possible multi- or large-scale variance in the uncertainty. It can be regarded as a "rule of thumb" to assess the accuracy of the spatial average of elevation changes if the area to be averaged over, $A_{1973}$ here, is larger than an area $A_{\text {cor }}$, within which errors in DEM differencing are considered as effectively correlated. $A_{\text {cor }}\left(\mathrm{m}^{2}\right)$ is defined as

$A_{\mathrm{cor}}=\pi \cdot L^{2}$.

The radius $L$ of this circular area is equal to the spatial correlation length. The variances of the elevation differences of both input DEMs over stable terrain were binned at $50 \mathrm{~m}$ intervals for scales $<1500 \mathrm{~m}$ and semivariograms produced. Analysing the latter, we find a mean correlation length of $400 \mathrm{~m}$ for the entire Swiss Alps. For glaciers with $A_{1973}>A_{\text {cor }}$, the uncertainty in the glacier-individual average elevation change $\sigma_{\Delta z, g}$ is calculated following Rolstad et al. (2009) as

$\sigma_{\Delta z, g}= \pm \sqrt{\sigma_{\Delta h, g}^{2} \cdot \frac{A_{\mathrm{cor}}}{5 \cdot A_{1973}}}$

where $\sigma_{\Delta h, g}(\mathrm{~m})$ is the standard deviation of the elevation error over stable terrain derived within a mask around individual glaciers (Fig.5a). For glaciers with $A_{1973}<A_{\text {cor }}$, elevation errors are treated as totally correlated in space, and $\sigma_{\Delta z, g}$ is equal to $\sigma_{\Delta h, g}$.

The glacier-individual uncertainty in volume change $\sigma_{\Delta V, g}\left(\mathrm{~m}^{3}\right)$ is obtained by multiplying $\sigma_{\Delta z, g}$ with the initial glacier area $A_{1973}$. A conservative estimate of the uncertainty in the total volume change over the entire Swiss Alps is derived by

$\sigma_{\Delta V, \text { tot }}= \pm \sum_{g=1}^{n} \sigma_{\Delta V, g}$ 

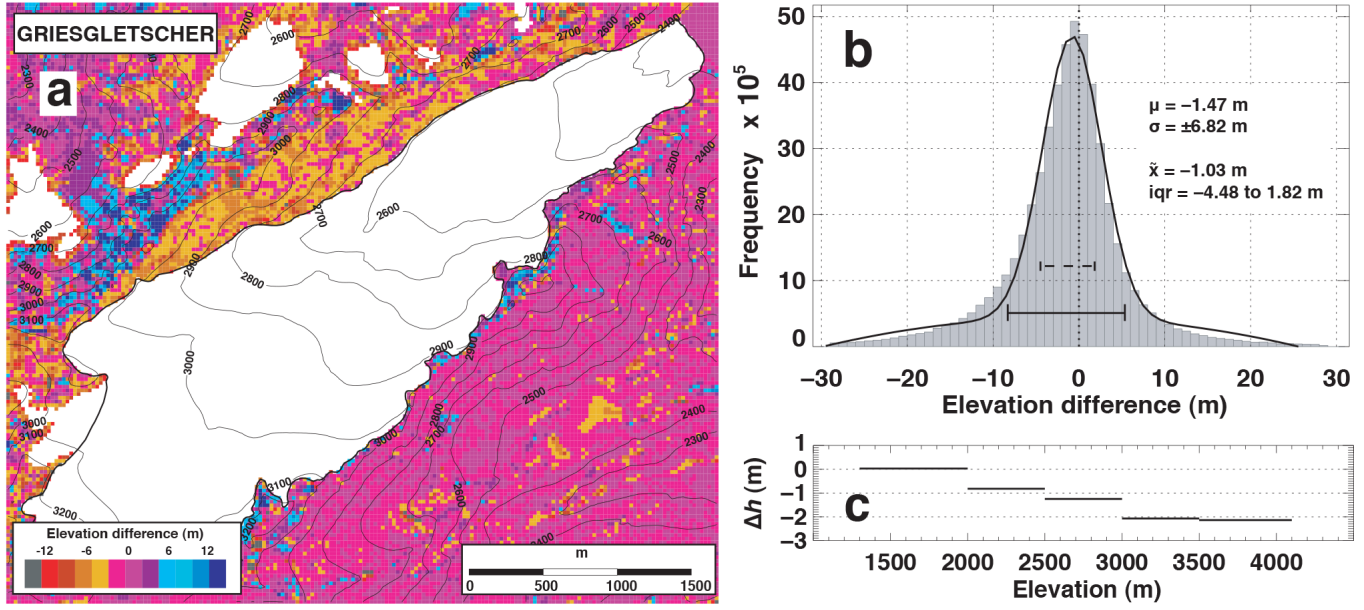

Figure 5. Comparison of input DEMs over stable terrain. (a) Spatial distribution of DEM differences outside the 1973 extents of Griesgletscher and adjacent smaller glaciers (masked out in white). (b) Frequency distribution of DEM differences over stable terrain around all glaciers. The black curve is a normal fit over the data, the solid bar marks standard deviation at the $1 \sigma$ level and the dashed bar marks the interquartile range (iqr). In addition, the mean $(\mu)$ and median $(\widetilde{x})$ elevation differences are given. (c) DEM differences over stable terrain around all glaciers averaged over $500 \mathrm{~m}$ elevation bands.

and results in $\pm 1.76 \mathrm{~km}^{3}$. The uncertainty in the geodetic mass balance of individual glacier entities $\sigma_{\text {geod, } g}$ (mw.e.) is calculated according to Huss et al. (2009) as

$\sigma_{\text {geod, } g}= \pm \sqrt{\left(\Delta z_{g} \cdot \sigma_{f_{\Delta V}}\right)^{2}+\left(f_{\Delta V} \cdot \sigma_{\Delta z, g}\right)^{2}}$,

with a conversion factor $f_{\Delta V}$ of 0.85 and a corresponding uncertainty $\sigma_{f_{\Delta V}}$ of 0.06 , derived from the assumed mean density of the total volume change of $850 \mathrm{~kg} \mathrm{~m}^{-3}$, and a corresponding uncertainty of $\pm 60 \mathrm{~kg} \mathrm{~m}^{-3}$ (Huss, 2013). The average geodetic elevation change $\Delta z$ is assumed to be uncorrelated to $f_{\Delta V}$. The resulting values for $\sigma_{\text {geod, } g}$ are then divided by the glacier-individual observation period length $(\Delta t)$ and range between \pm 0.02 and $\pm 0.36 \mathrm{~m}$ w.e. $\mathrm{yr}^{-1}$. After the glacier-individual reconstruction of the $t_{1}$ values, we consider $\Delta t$ as robust. Some uncertainty in $t_{2}$, and hence also in $\Delta t$, of maximum 2 years applies for only a few glaciers for which aerial orthophotographs used as source data for the creation of both the glacier outlines and DEMs at $t_{2}$ were acquired during 2 or more survey years (glaciers overlapping two or more areas of $t_{2}$ in Fig. 1).

Finally, the uncertainty in the average mass balance of all 1420 Swiss glaciers of the SGI2010 over the reference period $1980-2010 \sigma_{\overline{B_{\text {ref }}}}\left(\mathrm{m}\right.$ w.e. $\left.\mathrm{yr}^{-1}\right)$ is derived with

$\sigma_{\overline{B_{\mathrm{ref}}}}= \pm \frac{\sum_{g=1}^{n}\left(\left(\sigma_{\mathrm{geod}, g} / \Delta t\right) \cdot \overline{A_{g}}\right)}{\sum_{g=1}^{n} \overline{A_{g}}}$

where $\overline{A_{g}}$ is the average area of glacier $g$ between 1973 and 2010 and results in $\pm 0.07 \mathrm{~m}$ w.e. $\mathrm{yr}^{-1}$.

\subsection{Validation}

For validation of average mass balances between 1980 and 2010 we choose 31 glaciers from the data sets of Huss et al. (2010a, b), for which volume changes based on the independent, photogrammetrically derived DEMs show closest temporal accord with our respective observation period.

For individual glaciers, mean mass balance from Huss et al. (2010a, b) sometimes differs considerably from our results over the same period. Nevertheless, these differences do not indicate a systematic error and the mean difference is almost zero (Fig. 6). Hence, when analysing individual glaciers, the uncertainty in geodetic mass balance presented in this study has to be considered. Averaged over subsamples of glaciers or individual catchments though, the accuracy of the average geodetic mass balance is likely of the same order of magnitude as if derived with more precise source DEMs created, for instance, by photogrammetrical techniques.

\section{Results}

\subsection{Changes in surface elevation and area-altitude distribution}

The recent $\left(t_{2}\right)$ area-altitude distribution was derived from the combination of the SGI2010 with the swissALTI ${ }^{3 \mathrm{D}}$ DEMs. For $t_{1}$ the SGI1973 and the DHM25 Level 1 DEMs were used. Averaged over the entire Swiss Alps, observed area changes between 1973 and 2010 were largest between 2800 and $2900 \mathrm{~m}$ a.s.l. The most heavily glacierized areas were located almost $200 \mathrm{~m}$ higher in 2010 (Fig. 7a). For the observation period, the overall volume loss for the entire Swiss 


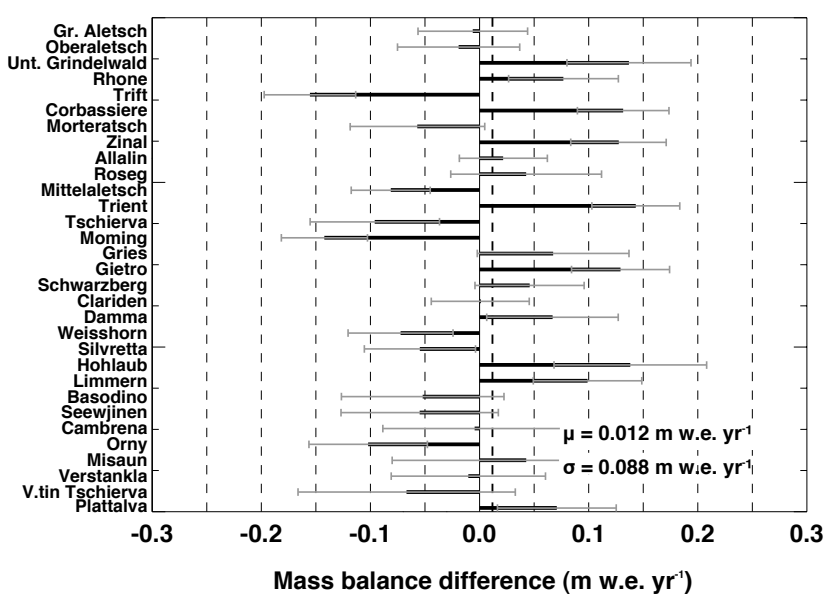

Figure 6. Validation of average geodetic mass balance with mass balance data derived from independent DEMs created using photogrammetry (Huss et al., 2010a, b). The mean difference $\mu$, for which the standard deviation at the $1 \sigma$ level is also given, is indicated with the bold dashed line. Individual glaciers are sorted according to their area. Error bars indicate the glacier-individual uncertainty in the geodetic mass balance $\left( \pm \sigma_{\text {geod, } g} / \Delta t\right)$.

Alps is $-22.51 \pm 1.76 \mathrm{~km}^{3}$, of which glaciers still present in 2010 account for $-22.37 \mathrm{~km}^{3}$. Averaged within $100 \mathrm{~m}$ elevation bands, volume loss was strongest between 2700 and $2800 \mathrm{~m}$ a.s.l. Corresponding average elevation changes were in good agreement with theoretical considerations by Schwitter and Raymond (1993) and continuously decreased from largest changes nearly at lowermost elevations (terminus of valley glaciers) towards zero in the accumulation area. No elevation bands with positive volume changes were detected (Fig. 7b). Both surface elevation and area changes were remarkable even above $3500 \mathrm{~m}$ a.s.l. (Fig. 7). The observed thinning at high altitudes and over the accumulation areas of glaciers results from a combination of ice flow dynamics and reduced accumulation and emphasizes the current state of disequilibrium of glaciers in the Swiss Alps.

\subsection{Average mass balance}

For the entire Swiss Alps, the area-weighted average mass balance of all 1420 glaciers included in the SGI2010 was $-0.62 \pm 0.07 \mathrm{~m}$ w.e. $\mathrm{yr}^{-1}$ during our reference period 1980 2010. For the main hydrological catchments, it ranged between -0.52 and $-1.07 \mathrm{~m}$ w.e. $\mathrm{yr}^{-1}$ (Fig. $8, \overline{B_{\text {ref }}}$ in Table 1). Catchments along the north side of the Alps (Aare, Reuss, Linth) showed nearly the same mass changes ( $-0.63 \mathrm{~m}$ w.e. $\mathrm{yr}^{-1}$ on average) as for all of Switzerland. In general, glaciers in the Valais Alps (Rhone, Doveria) lost comparatively less $\left(-0.59 \mathrm{~m}\right.$ w.e. $\left.\mathrm{yr}^{-1}\right)$ and glaciers south of the main Alpine crest (Maggia, Ticino, Maira, Poschiavino) and of the inner-Alpine Inn valley comparatively more $\left(-0.84 \mathrm{~m}\right.$ w.e. $\left.\mathrm{yr}^{-1}\right)$ mass than on average over the entire Swiss Alps. These differences might be attributed to region-
Table 1. Mean geodetic mass balance 1980-2010 for the main hydrological catchments of Switzerland shown in Fig. 8, listed in alphabetic order.

\begin{tabular}{lrrrrr}
\hline Catchment & \multicolumn{3}{c}{ Glacierized Area } & \multicolumn{3}{c}{ Glacierization } & $\overline{B_{\text {ref }}}$ \\
& $\left(\mathrm{km}^{2}\right)$ & $\left(\mathrm{km}^{2}\right)$ & $\begin{array}{r}(\%) \\
(\%)\end{array}$ & $\begin{array}{r}\left(\mathrm{m} \text { w.e. } \mathrm{yr}^{-1}\right) \\
\end{array}$ \\
\hline Alpenrhein & 57.2 & 2010 & 1973 & 2010 & \\
Linth & 23.3 & 16.0 & 1.78 & 0.84 & -0.69 \\
Reuss & 102.5 & 75.7 & 3.03 & 2.23 & -0.60 \\
Aare b. Brugg & 229.8 & 174.5 & 1.97 & 1.50 & -0.62 \\
Rhone & 721.5 & 569.2 & 13.68 & 10.79 & -0.59 \\
Doveria & 14.1 & 8.8 & 8.24 & 5.12 & -0.52 \\
Maggia & 5.0 & 3.0 & 0.39 & 0.23 & -0.83 \\
Ticino & 5.9 & 2.2 & 0.39 & 0.14 & -0.67 \\
Maira & 20.4 & 13.0 & 10.76 & 6.86 & -1.07 \\
Poschiavino & 9.5 & 6.9 & 5.60 & 4.06 & -0.74 \\
Inn & 71.9 & 46.4 & 3.71 & 2.39 & -0.81 \\
\hline All catchments & 1261.2 & 942.8 & 3.89 & 3.04 & -0.62 \\
\hline
\end{tabular}

ally variable changes in the climatic forcing, glacier sensitivity and/or topographic effects.

The close-ups of the eastern Bernese Alps/western Alps of Central Switzerland (Fig. 9) and the central/eastern Valais Alps (Fig. 10) show a high spatial variability in the temporally homogenized geodetic mass balance 1980-2010. Individual glaciers showed strongly differing responses to a similar change in regional climate forcing. For most of the largest valley glaciers with flat termini (e.g. Unteraargletscher (UAR), Oberaletschgletscher (OAL) and Grosser Aletschgletscher (ALE) in Fig. 9 or Gornergletscher (GOR) and Glacier d'Otemma (OTE) in Fig. 10), mass changes were particularly high. In contrast, Fieschergletscher (FIE in Fig. 9) or Findelengletscher (FIN in Fig. 10) showed smaller mass loss. For small and very small glaciers, the scatter of resulting changes was maximal. Neighbouring glaciers sometimes exhibited a high spatial variability in observed geodetic mass changes (e.g. glaciers in the vicinity of ALE and UAR in Fig. 9 or glaciers close to OTE or within the Weissmiesgruppe in Fig. 10), while for other regions the response was quite uniform (e.g. Rotondogruppe or Blüemlisalp near Kanderfirn (KAN) in Fig. 9). Mass losses of the mostly mediumsized mountain and valley glaciers of the Mischabel- and Weisshorngruppe were also very uniform and comparatively moderate (Fig. 10). This is likely due in a major part to the continentality of these high-lying areas, influenced by one of the coldest and driest climate regimes in the entire Swiss Alps (e.g. Frei and Schär, 1998; Auer et al., 2007). The equilibrium line altitudes are highest for these glaciers (Maisch et al., 2000) and their sensitivity to changes in air temperature and precipitation is expected to be lowest (Oerlemans and Reichert, 2000). 

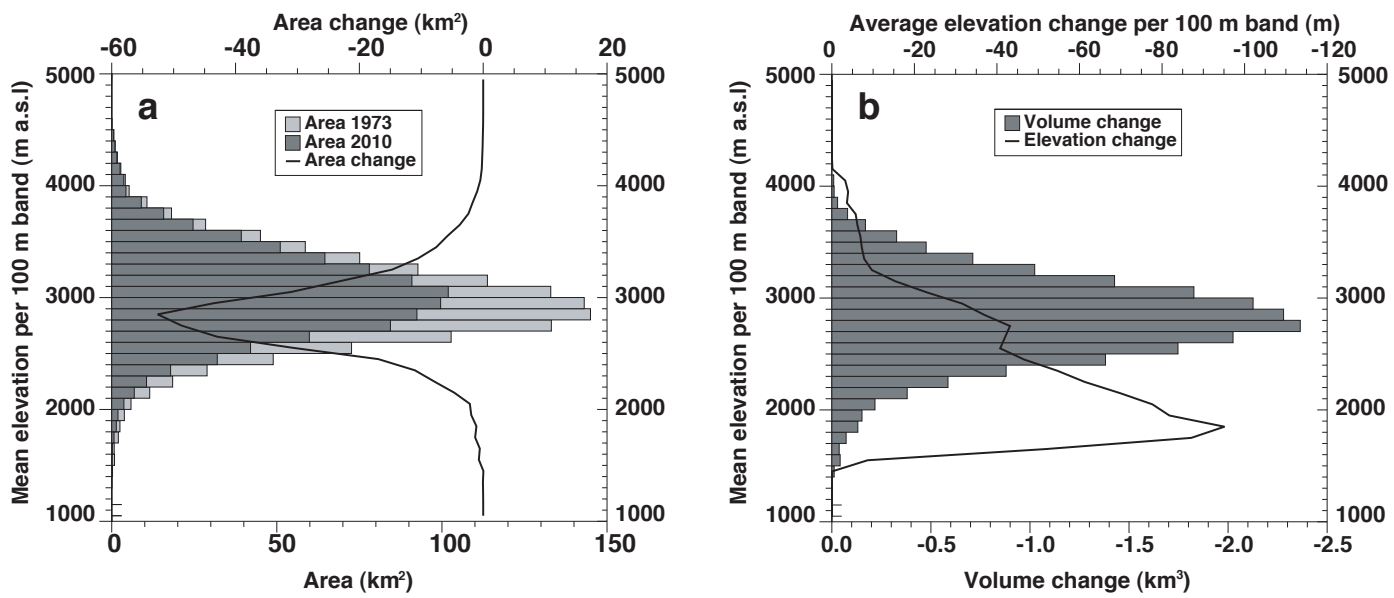

Figure 7. (a) Area-elevation distribution in 1973 and 2010 in $100 \mathrm{~m}$ elevation bands and corresponding area changes between the two inventories. (b) Elevation distribution of the observed volume changes within the observation period as well as resulting average elevation changes per $100 \mathrm{~m}$ elevation bands.

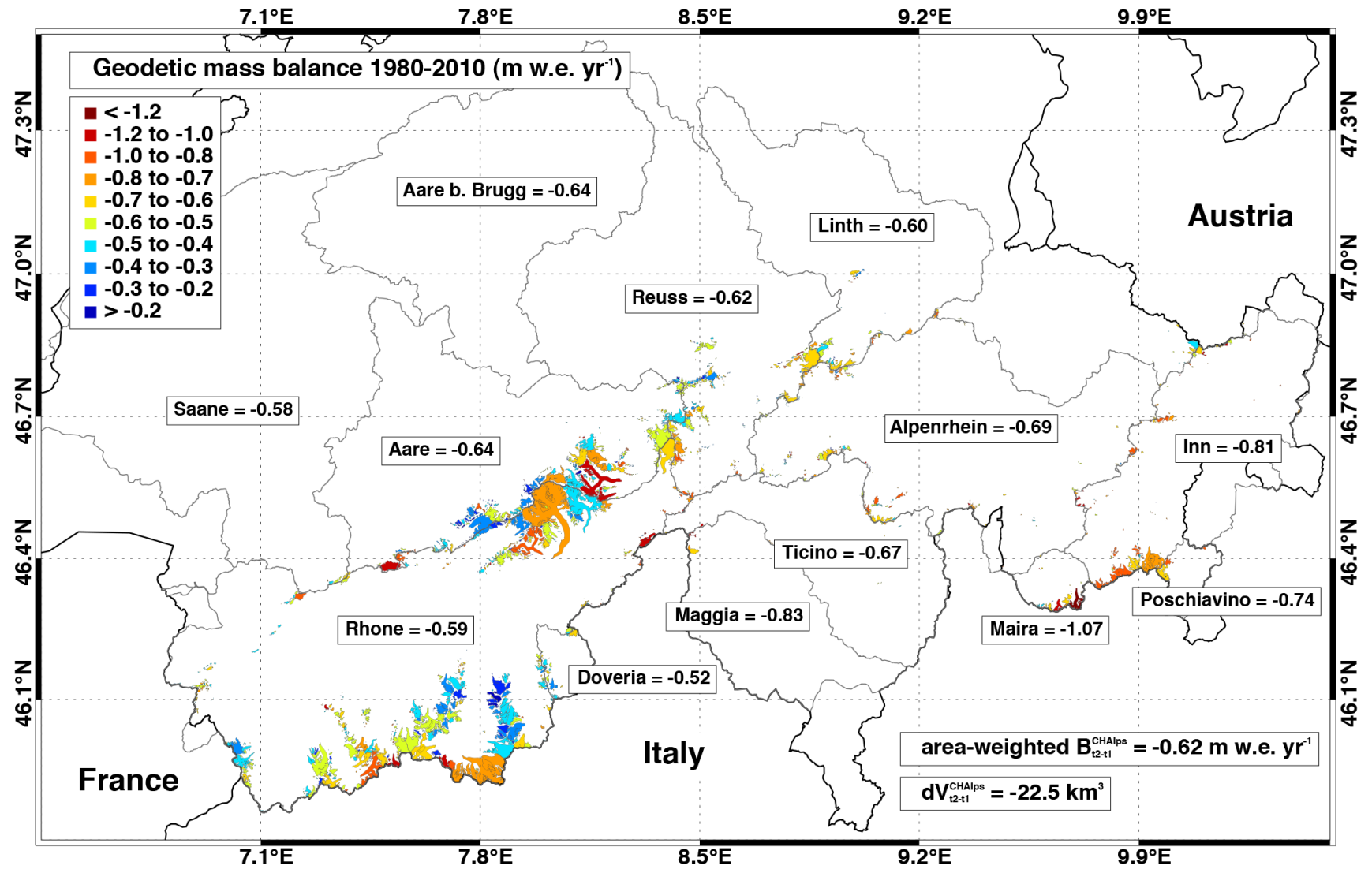

Figure 8. Mean area-weighted geodetic mass balance 1980-2010 for the main hydrological catchments and the entire Swiss Alps.

\subsection{Geometrical indices and long-term mass balance variability}

For individual glaciers, the relation between the observed geodetic mass changes of 1980-2010 and the explaining ge- ometrical indices of (1) glacier area, (2) median elevation, (3) mean slope of the glacier terminus and (4) mean aspect were not straightforward. Neither average area during 1973 $2010(r=-0.09)$ nor mean aspect $(r=0.03)$ were significantly correlated with the geodetic mass balance (Fig. 11a, 


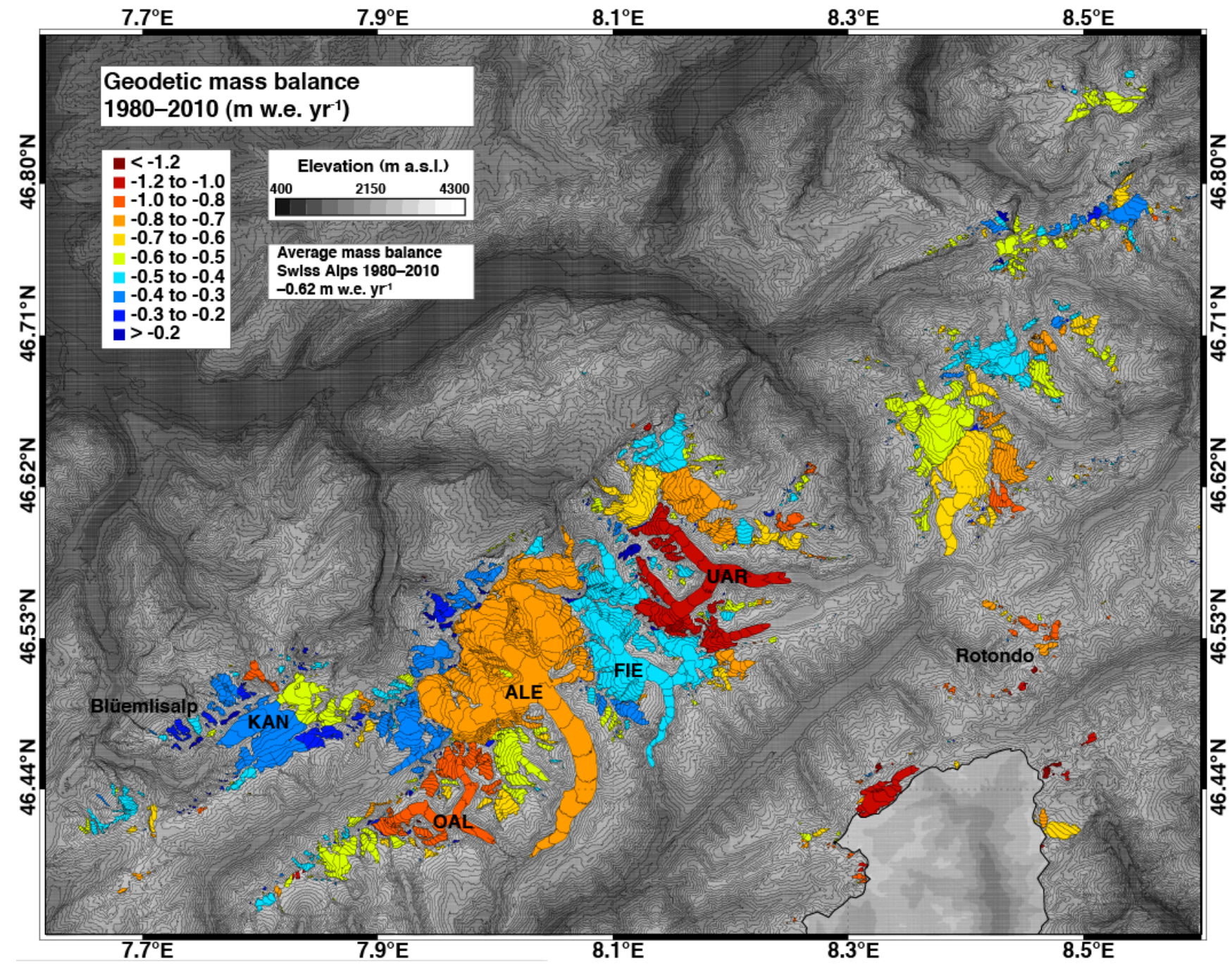

Figure 9. Spatial distribution of the temporally homogenized geodetic mass balance 1980-2010 for the eastern Bernese Alps/western Alps of Central Switzerland. The SGI2010 outlines are taken to illustrate glacier surface area.

d). A weak correlation $(r=0.22)$ was found for median elevation at $t_{1}$ (Fig. 11b) and a stronger one $(r=0.42)$ for mean slope over the lowermost $25 \%$ of the glacier surface at $t_{1}$ (Fig. 11c). Because part of the significant scatter in Fig. 11a-c is likely caused by glacier-specific uncertainties and local effects, we also calculated the respective mean values for $5 \%$ quantiles of the data (red triangles in Fig. 11a-c) by computing the mean average mass balance for 20 classes of equal sample size. Then, a more structured relation between the selected geometrical indices and long-term mass balance variability emerges. For average area of 1973-2010, the correlation is negative. However, if the smallest glaciers $\left(<0.1 \mathrm{~km}^{2}\right)$ are neglected, mean average mass balances did not vary considerably for different size classes (Fig. 11a). For median elevation, the correlation is positive. The higher the median elevation of a glacier at $t_{1}$, the less negative the average mass budget tends to be (Fig. 11b). Median eleva- tion is a proxy for the balanced-budget equilibrium line altitude (ELA $)_{0}$ (Braithwaite et al., 2013), which in turn depends on continentality. The latter can be approximated as a function of mean annual air temperature and precipitation at the $\mathrm{ELA}_{0}$ (Shumsky, 1964; Haeberli et al., 1989). Glaciers influenced by more maritime climatic conditions react more sensitively to changes in air temperature and precipitation than more continental glaciers do (Oerlemans and Reichert, 2000) and are thus expected to show more negative mass balance in a period of global warming. For mean slope of the glacier terminus, the correlation is again positive. The more gently sloping the glacier's ablation area at $t_{1}$, here approximated with the glacier surface over the lowermost $25 \%$ at $t_{1}$, the more negative the average mass budget (Fig. 11c). The flattest glacier termini are typically those of larger valley glaciers, which also show comparatively more negative mass balances due to their longer response times (Hoelzle 


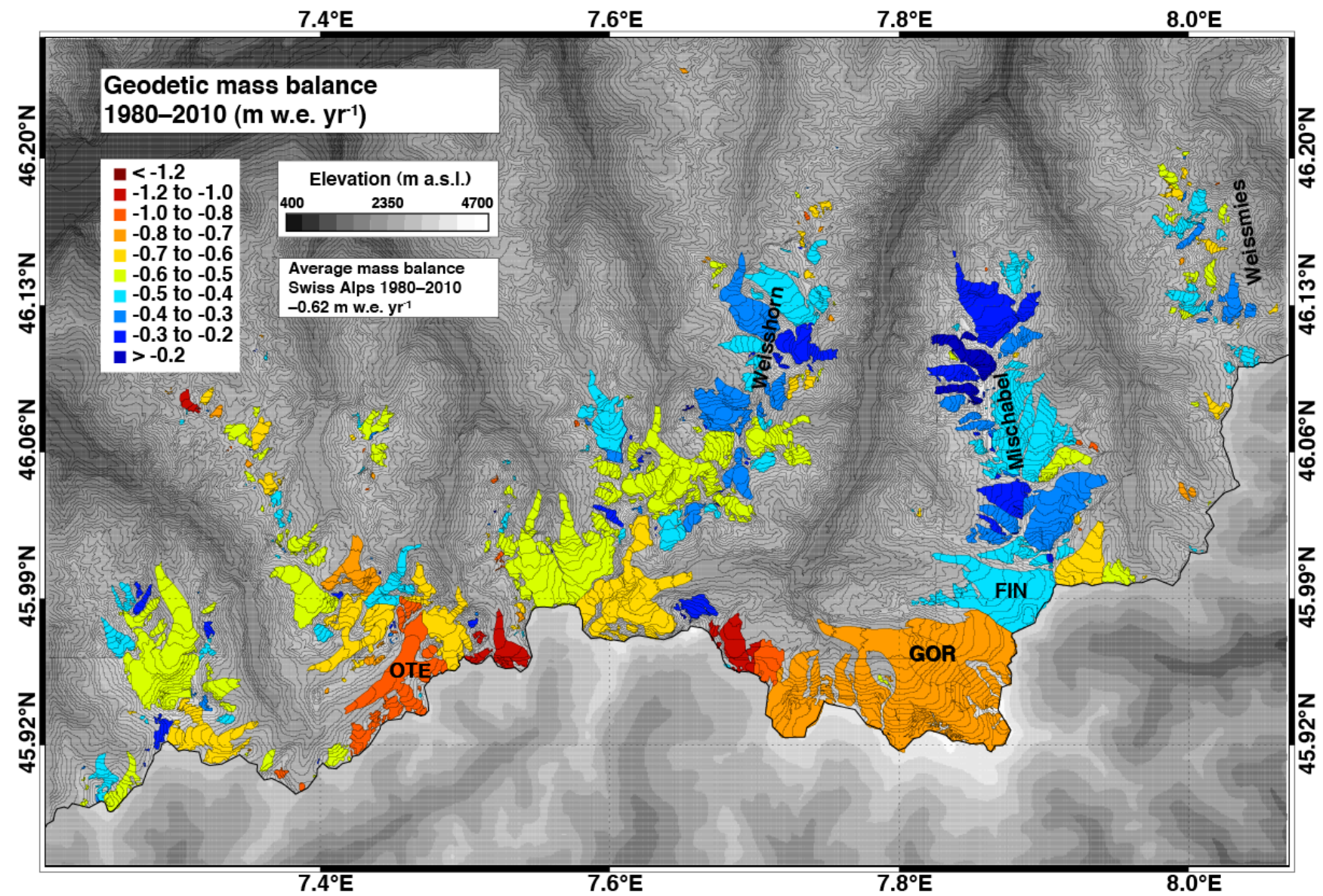

Figure 10. Spatial distribution of the temporally homogenized geodetic mass balance 1980-2010 for the central/eastern Valais Alps. The SGI2010 outlines are taken to illustrate glacier surface area.

et al., 2003). Furthermore, they usually flow down into narrow valley bottoms at low altitudes (Maisch et al., 2000). There, higher air temperatures are in favour of increased melt rates, and the effects of surface albedo lowering (accumulation of dust) and mass balance vs. altitude (fast vertical ice thickness loss) act as self-reinforcing mechanisms (Haeberli et al., 2007; Oerlemans et al., 2009). North-eastexposed glaciers lost most mass, southwest-exposed glaciers lost least (Fig. 11d). This is likely due to the different sensitivity to changes in air temperature increase for the respective classes of mean aspect (Evans and Cox, 2005; Evans, 2006). Because of the stronger influence of the shortwave radiation component and the fact that they are located at higher elevation, south-exposed glaciers generally react less sensitively to air temperature changes than north-exposed glaciers. Also, south-exposed glaciers are often smaller and thinner and therefore generally have a shorter response time and thus less negative mass balance.

\section{Comparison to other studies for the European Alps}

For the 1420 glaciers included in the SGI2010, the average mass balance of $-0.62 \pm 0.07 \mathrm{~m}$ w.e. $\mathrm{yr}^{-1}$ calculated over the reference period 1980-2010 is comparable to observed mass changes reported for other glacierized regions of the European Alps for recent years. Carturan et al. (2013a) computed an average mass budget of $-0.69 \pm 0.12 \mathrm{~m}$ w.e. $\mathrm{yr}^{-1}$ between the early 1980s and the mid-2000s for glaciers of the Ortler Alps group on the southwestern border of South Tyrol, Italy. Applying our method for temporal homogenization of mass changes derived from DEM differencing (cf. Sect. 3.1, Fig. 3), we calculate $-0.65 \mathrm{~m}$ w.e. $\mathrm{yr}^{-1}$ for the Swiss Alps when averaged over the same time period as analyzed by Carturan et al. (2013a). From area and volume changes reported by Abermann et al. (2009) for the Austrian Ötztal Alps between 1969 and 2006, we calculate a mean mass balance of $-0.40 \mathrm{~m}$ w.e. $\mathrm{yr}^{-1}$ averaged for 81 glaciers. The average mass balance for all Swiss glaciers is $-0.39 \mathrm{~m}$ w.e. $\mathrm{yr}^{-1}$ from 1969 to 2006.

To derive surface elevation and mass changes for the entire Swiss Alps, Paul and Haeberli (2008) compared the 

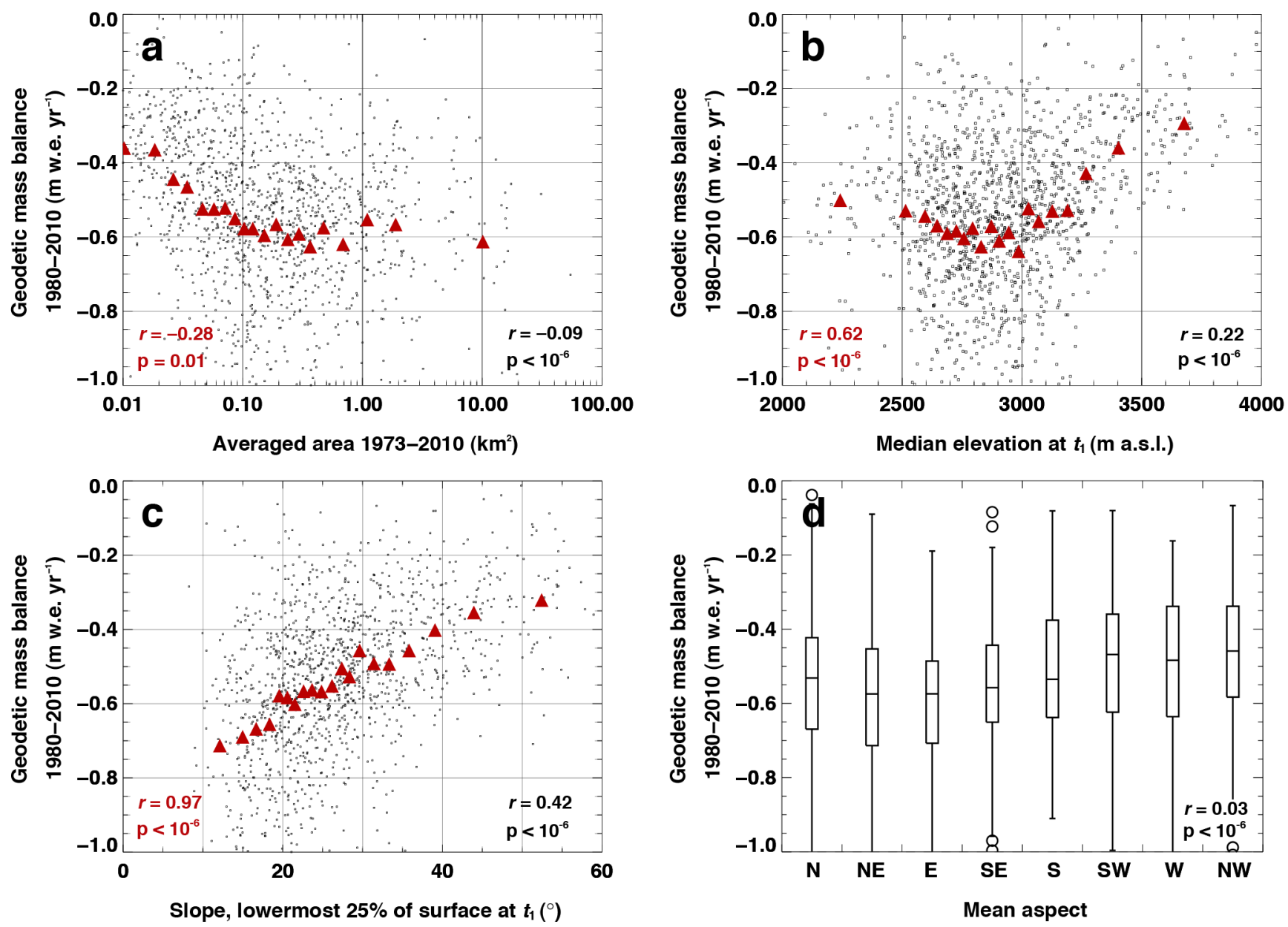

Figure 11. Correlation of temporally homogenized geodetic mass balance 1980-2010 and several geometrical indices. (a) Average area 1973-2010, (b) median elevation at $t_{1}$, (c) surface slope averaged over the lowermost $25 \%$ of the glacier and (d) mean aspect, where black boxes enclose the interquartile range (iqr) of the data, defined at iqr75-iqr25, and whiskers extend out to the maximum or minimum value of the data, or to 1.5 times either the iqr75 or iqr 25 when there is data beyond this range. Outliers are identified with small circles. Red triangles show mean values for $5 \%$ quantiles of the data. $r$ is the linear correlation coefficient and $\mathrm{p}$ the significance level of the respective relation (black always refers to the whole data set, while red refers to the mean values for the $5 \%$ quantiles only).

DHM25 Level 1 DEMs to the SRTM DEM from February 2000 and combined the former with the SGI1973 and the latter with the SGI2000 created from medium-resolution $(30 \mathrm{~m})$ satellite imagery. They assumed $t_{1}=1985$ as constant and report an average mass balance of $-0.78 \mathrm{~m}$ w.e. $\mathrm{yr}^{-1}$ between 1985 and 1999. Over the same reference period, we find a cumulative average mass balance for all Swiss glaciers of $-0.60 \mathrm{~m}$ w.e. $\mathrm{yr}^{-1}$ by temporally homogenizing mass changes derived from DEM differencing (cf. Eq. 3). Both the quality of the different source data used and methodologies applied contribute to the differences in derived average mass balance. According to Jarvis et al. (2008), the vertical accuracy of the $90 \mathrm{~m}$ resolution SRTM DEM is $\pm 30 \mathrm{~m}$. Over glacierized areas in Switzerland, however, it is probably considerably more accurate (Paul, 2008). Nevertheless, the quality of the SRTM DEM is not comparable to the recently compiled $2 \mathrm{~m}$ swissALTI ${ }^{3 \mathrm{D}}$ DEMs. If the
SRTM DEM is used, the impacts of the penetration of radar waves into snow and ice need to be considered (Berthier et al., 2006; Gardelle et al., 2012b) because penetration can reach as much as $10 \mathrm{~m}$ for the SRTM C-band radar (Dall et al., 2001). This could explain the more negative surface elevation changes over accumulation areas observed by Paul and Haeberli (2008) who compared the SRTM DEM to photogrammetrically derived DEMs by Bauder et al. (2007). If all of the difference between the average 1985-1999 mass balance from Paul and Haeberli (2008) and our approach was attributed to the penetration of the radar signal into snow and ice, one could infer a mean penetration of the SRTM C-band of about $8 \mathrm{~m}$ beneath the February 2000 surface (calculated as $0.18 \mathrm{~m}$ w.e. $\mathrm{yr}^{-1} \times 14$ years, divided by an assumed mean firn density of $650 \mathrm{~kg} \mathrm{~m}^{-3}$ and an accumulation area ratio of $0.5)$. This would be somewhat higher than values reported for the Karakoram (Gardelle et al., 2012b) or southeastern 
Alaska (Melkonian et al., 2014). In addition, preprocessing of the DEM prior to differencing may cause uncertainty if the source DEMs have to be downscaled to the same grid cell resolution (Carturan et al., 2013a). For our study, the $2 \mathrm{~m}$ resolution swissALTI ${ }^{3 \mathrm{D}}$ DEMs were upscaled to $25 \mathrm{~m}$, corresponding to the cell size of the DHM25 Level 1 DEMs. The quality of both the source DEMs and the glacier outlines used is important, especially if changes of small and very small glaciers have to be assessed. Fischer et al. (2014) showed that the accuracy of glacier outlines derived from semi-automated satellite remote sensing approaches using medium-resolution satellite imagery does not satisfy the requirements for change assessments of glaciers $<1.0 \mathrm{~km}^{2}$.

Related to the methodological approaches used, the following issues likely also contribute to the differences in calculated average mass balances between Paul and Haeberli (2008) and this study: assuming a density of the volumetric change of $900 \mathrm{~kg} \mathrm{~m}^{-3}$ implies that neither the mean firn density nor the firn thickness and area changed over the observation period. For glaciers in the European Alps, however, significant changes in both firn extent and density have been reported (e.g. Carturan et al., 2013a; Helfricht et al., 2014). Following Huss (2013), we apply a mean conversion factor of $850 \mathrm{~kg} \mathrm{~m}^{-3}$ here. Furthermore, the average mass balance of individual glaciers (Eq. 2) can be significantly biased if differences in the reference years of the source data are not considered. For Grosser Aletschgletscher, assuming $t_{1}$ as 1985 instead of 1980 changes the result by $0.14 \mathrm{~m}$ w.e. $\mathrm{yr}^{-1}$ $\left(-0.87\right.$ instead of $-0.73 \mathrm{~m}$ w.e. $\left.\mathrm{yr}^{-1}\right)$. Defining $t_{1}$ as 1985 for all glaciers in Switzerland would change the mean geodetic mass balance by $0.03 \mathrm{~m}$ w.e. $\mathrm{yr}^{-1}$. Hence, differences in the reference years of the source data explain $17 \%$, differences in the assumptions made regarding the density of volume change $24 \%$, and differences in the quality of the source data used $59 \%$ of the disagreement between the calculated average mass balances reported here and those reported by Paul and Haeberli (2008).

\section{Conclusions}

We presented glacier-specific changes in surface elevation, volume and geodetic mass balance for all glaciers in the Swiss Alps between 1980 and 2010. The DHM25 Level 1 DEMs acquired from 1961 to 1991 over glacierized areas were combined with the 1973 glacier inventory and compared to the swissALTI ${ }^{3 \mathrm{D}}$ DEMs from 2008 to 2011 and glacier outlines from the new Swiss Glacier Inventory SGI2010. By making use of these recently compiled new source data of improved quality, we were able to recompute and extend the data set of surface elevation changes in the Swiss Alps by Paul and Haeberli (2008). From the DEM differencing we derive an overall volume loss of $-22.51 \pm 1.76 \mathrm{~km}^{3}$ for the entire Swiss Alps for the observation period. Glaciers still present in 2010 ac- count for $-22.37 \mathrm{~km}^{3}$ of this change. Observed glacier volume changes were greatest between 2700 and $2800 \mathrm{~m}$ a.s.l. and still noticeable above $3500 \mathrm{~m}$ a.s.l. No elevation bands with positive elevation changes were identified. Results were validated against elevation changes from independent photogrammetrically derived DEMs. An in-depth accuracy assessment of the computed volume and mass changes of the glaciers investigated was performed. Elevation-, slopeand aspect-dependent errors were investigated by comparison of both source DEMs over stable terrain outside the glaciers. Because of significant differences in the acquisition dates of individual DEMs, annual mountain-range mass balance variability (Huss, 2012) was used to temporally homogenize the geodetic mass changes to the reference time interval 1980-2010. Over this period, the area-weighted mean geodetic mass balance for the entire Swiss Alps was $-0.62 \pm 0.07 \mathrm{~m}$ w.e. $\mathrm{yr}^{-1}$. For the main hydrological catchments of Switzerland, mean balances ranged from -0.52 to $-1.07 \mathrm{~m}$ w.e. $\mathrm{yr}^{-1}$.

To better understand the spatial variability of the observed surface elevation and mass changes, we investigated the relationship between observed mass changes and topographic factors. Overall, as shown by several previous studies, differences in glacier hypsometry can partly explain the general pattern of glacier responses to changes in climatic forcing. We found strongest correlations for the geometrical indices terminus slope (i.e. mean over the lowermost $25 \%$ ) and median elevation.

The data set presented in this article is useful for various future studies and applications. For instance, both massbalance-driven glacier evolution models for the entire Swiss Alps and extrapolations of the measured mass balances of single glaciers to entire catchments can be validated and improved. This would also imply a reduction in the uncertainty of future runoff projections from glacierized basins in Switzerland. Moreover, it is a valuable starting point for testing more sophisticated methods to explain the spatial variability in long-term mass balance.

Acknowledgements. This study was supported by the Swiss National Science Foundation (SNSF), grant 200021_137586. The SWISSIMAGE and swissALTI ${ }^{3 \mathrm{D}}$ data sets were purchased from the Swiss Federal Office of Topography, license no. 5704003629. Special thanks to the Laboratory of Hydraulics, Hydrology and Glaciology (VAW) at the ETH Zurich for providing us with photogrammetrically derived DEMs available for selected Swiss glaciers over our period of interest, to M. Rickenbacher, Y. Weidmann, and to the Department of Geography at the University of Zurich for providing us with the 1973 outlines in digital format. Finally, thanks to the scientific editor M. Sharp and to three anonymous reviewers, whose comments were helpful for finalizing the paper.

Edited by: M. Sharp 


\section{References}

Abermann, J., Lambrecht, A., Fischer, A., and Kuhn, M.: Quantifying changes and trends in glacier area and volume in the Austrian Ötztal Alps (1969-1997-2006), The Cryosphere, 3, 205215, doi:10.5194/tc-3-205-2009, 2009.

Abermann, J., Fischer, A., Lambrecht, A., and Geist, T.: On the potential of very high-resolution repeat DEMs in glacial and periglacial environments, The Cryosphere, 4, 53-65, doi:10.5194/tc-4-53-2010, 2010.

Abermann, J., Kuhn, M., and Fischer, A.: Climatic controls of glacier distribution and glacier changes in Austria, Ann. Glaciol., 52, 83-90, 2011.

Auer, I., Böhm, R., Jurkovic, A., Lipa, W., Orlik, A., Potzmann, R., Schöner, W., Ungersböck, M., Matulla, C., Briffa, K., Jones, P., Efthymiadis, D., Brunetti, M., Nanni, T., Maugeri, M., Mercalli, L., Mestre, O., Moisselin, J., Begert, M., Müller-Westermeier, G., Kveton, V., Bochnicek, O., Stastny, P., Lapin, M., Szalai, S., Szentimrey, T., Cegnar, T., Dolinar, M., Gajic-Capka, M., Zaninovic, K., Majstorovic, Z., and Nieplova, E.: HISTALP - historical instrumental climatological surface time series of the Greater Alpine Region, Int. J. Climatol., 27, 17-46, 2007.

Bauder, A., Funk, M., and Huss, M.: Ice-volume changes of selected glaciers in the Swiss Alps since the end of the 19th century, Ann. Glaciol., 46, 145-149, 2007.

Benn, D. I. and Evans, D. J. A.: Glaciers and Glaciation, Hodder Education, London, 802 pp., 2010.

Benn, D. I. and Lehmkuhl, F.: Mass balance and equilibrium-line altitudes of glaciers in high-mountain environments, Quat. Int., 65-66, 15-29, 2000.

Berthier, E., Arnaud, Y., Vincent, C., and Rémy, F.: Biases of SRTM in high-mountain areas: implications for the monitoring of glacier volume changes, Geophys. Res. Lett., 33, L08502, doi:10.1029/2006GL025862, 2006.

Berthier, E., Schiefer, E., Clarke, G. K. C., Menounos, B., and Rémy, F.: Contribution of Alaskan glaciers to sea-level rise derived from satellite imagery, Nat. Geosci., 3, 92-95, doi:10.1038/ngeo737, 2010.

Bolch, T., Buchroithner, M., Pieczonka, T., and Kunert, A.: Planimetric and volumetric glacier changes in the Khumbu Himal, Nepal, since 1962 using Corona, Landsat TM and ASTER data, J. Glaciol., 54, 592-600, 2008.

Braithwaite, R. J., Raper, S. C. B., and Candela, R.: Recent changes (1991-2010) in glacier mass balance and air temperature in the European Alps, Ann. Glaciol., 54, 139-146, doi:10.3189/2013AoG63A285, 2013.

Carturan, L., Filippi, R., Seppi, R., Gabrielli, P., Notarnicola, C., Bertoldi, L., Paul, F., Rastner, P., Cazorzi, F., Dinale, R., and Dalla Fontana, G.: Area and volume loss of the glaciers in the Ortles-Cevedale group (Eastern Italian Alps): controls and imbalance of the remaining glaciers, The Cryosphere, 7, 13391359, doi:10.5194/tc-7-1339-2013, $2013 \mathrm{a}$.

Carturan, L., Baldassini, G. A., Bondesan, A., Calligaro, S., Carton, A., Cazorzi, F., Dalla Fontana, G., Francese, R., Guarnieri, A., Milan, N., Moro, D., and Tarolli, P.: Current behaviour and dynamics of the lowermost Italian glacier (Montasio Occidentale, Julian Alps), Geogr. Ann. A, 95, 79-96, doi:10.1111/geoa.12002, 2013b.
Cox, L. H. and March, R. S.: Comparison of geodetic and glaciological mass-balance techniques, Gulkana Glacier, Alaska, U.S.A., J. Glaciol., 50, 363-370, 2004.

Dall, J., Madsen, S. N., Keller, K., and Forsberg, R.: Topography and Penetration of the Greenland Ice Sheet Measured with Airborne SAR Interferometry, Geophys. Res. Lett., 28, 1703-1706, 2001.

DeBeer, C. and Sharp, M.: Topographic influences on recent changes of very small glaciers in the Monashee Mountains, British Columbia, Canada, J. Glaciol., 55, 691-700, 2009.

Diolaiuti, G. A., Bocchiola, D., Vagliasindi, M., D’Agata, C., and Smiraglia, C.: The 1975-2005 glacier changes in Aosta Valley (Italy) and the relations with climate evolution, Progr. Phys. Geogr., 36, 764-785, 2012.

Evans, I. S.: Glacier distribution in the Alps: statistical modelling of altitude and aspect, Geogr. Ann. A, 88, 115-133, 2006.

Evans, I. S. and Cox, N. J.: Global variations of local asymmetry in glacier altitude: separation of north-south and east-west components, J. Glaciol., 51, 469-482, 2005.

Fischer, A.: Comparison of direct and geodetic mass balances on a multi-annual time scale, The Cryosphere, 5, 107-124, doi:10.5194/tc-5-107-2011, 2011.

Fischer, M., Huss, M., Barboux, C., and Hoelzle, M.: The new Swiss Glacier Inventory SGI2010: Relevance of using highresolution source data in areas dominated by very small glaciers, Arct., Antarct. Alp. Res., 46, 935-947, doi:10.1657/1938-424646.4.933, 2014.

Frei, C. and Schär, C.: A precipitation climatology of the Alps from high-resolution rain-gauge observations, Int. J. Climatol., 18, 873-900, 1998.

Furbish, D. J. and Andrews, J. T.: The use of hypsometry to indicate long-term stability and response of valley glaciers to changes in mass transfer, J. Glaciol., 30, 199-211, 1984.

Gardelle, J., Berthier, E., and Arnaud, Y.: Slight mass gain of Karakoram glaciers in the early twenty-first century, Nat. Geosci., 5, 322-325, doi:10.1038/ngeo1450, 2012a.

Gardelle, J., Berthier, E., and Arnaud, Y.: Impact of resolution and radar penetration on glacier elevation changes computed from DEM differencing, J. Glaciol., 58, 419-422, 2012 b.

Gardent, M., Rabatel, A., Dedieu, J.-P., and Deline, P.: Multitemporal glacier inventory of the French Alps fromthe late 1960s to the late 2000s, Global Planet. Change, 120, 24-37, 2014.

Gardner, A. S., Moholdt, G., Cogley, J. G., Wouters, B., Arendt, A. A., Wahr, J., Berthier, E., Hock, R., Pfeffer, W. T., Kaser, G., Ligtenberg, S. R. M., Bolch, T., Sharp, M. J., Hagen, J. O., van den Broecke, M. R., and Paul, F.: A reconciled estimate of glacier contributions to sea level rise: 2003 to 2009, Science, 340, 852857, 2013.

Glaciological Reports: The Swiss Glaciers, 1958/1959-2010/11, No. 80-132, Yearbooks of the Cryospheric Commission of the Swiss Academy of Sciences (SCNAT), Laboratory of Hydraulics, Hydrology and Glaciology (VAW) of ETH Zurich, Zurich, 1960-2015.

Haeberli, W., Alean, J.-C., Müller, P., and Funk, M.: Assessing risks from glacier hazards in high mountain regions: some experiences in the Swiss Alps, Ann. Glaciol., 13, 77-101, 1989.

Haeberli, W., Hoelzle, M., Paul, F., and Zemp, M.: Integrated monitoring of mountain glaciers as key indicators of global climate change: the European Alps, Ann. Glaciol., 46, 150-160, 2007. 
Helfricht, K., Kuhn, M., Keuschnig, M., and Heilig, A.: Lidar snow cover studies on glaciers in the Ötztal Alps (Austria): comparison with snow depths calculated from GPR measurements, The Cryosphere, 8, 41-57, doi:10.5194/tc-8-41-2014, 2014.

Hoelzle, M., Haeberli, W., Dischl, M., and Peschke, W.: Secular glacier mass balances derived from cumulative glacier length changes, Global Planet. Change, 36, 295-306, 2003.

Hughes, P. D.: Twenty-first century glaciers and climate in the Prokletije Mountains, Albania, Arct., Antarct. Alp. Res., 41, 455-459, 2009.

Huss, M.: Present and future contribution of glaciers to runoff from macroscale drainage basins in Europe, Water Resour. Res., 47, W07511, doi:10.1029/2010WR010299, 2011.

Huss, M.: Extrapolating glacier mass balance to the mountain-range scale: the European Alps 1900-2100, The Cryosphere, 6, 713727, doi:10.5194/tc-6-713-2012, 2012.

Huss, M.: Density assumptions for converting geodetic glacier volume change to mass change, The Cryosphere, 7, 877-887, 2013, http://www.the-cryosphere-discuss.net/7/877/2013/.

Huss, M. and Farinotti, D.: Distributed ice thickness and volume of all glaciers around the globe, J. Geophys. Res., 117, F04010, doi:10.1029/2012JF002523, 2012.

Huss, M., Bauder, A., and Funk, M.: Homogenization of long-term mass balance time series, Ann. Glaciol., 50, 198-206, 2009.

Huss, M., Hock, R., Bauder, A., and Funk, M.: 100-year mass changes in the Swiss Alps linked to the Atlantic Multidecadal Oscillation, Geophys. Res. Lett., 37, L10501, doi:10.1029/2010GL042616, 2010a.

Huss, M., Usselmann, S., Farinotti, D., and Bauder, A: Glacier mass balance in the south-eastern Swiss Alps since 1900 and perspectives for the future, Erdkunde, 64, 119-140, doi:10.3112/erdkunde.2010.02.02, 2010b.

Huss, M., Hock, R., Bauder, A., and Funk., M.: Conventional versus reference-surface mass balance, J. Glaciol., 58, 278-286, 2012.

IPCC: Climate Change 2013, The Physical Science Basis, Working Group I Contribution to the Fifth Assessment Report of the Intergovernmental Panel on Climate Change, WMO / UNEP, Cambridge University Press, Geneva, 2013.

Jarvis, A., Reuter, H. I., Nelson, A., and Guevara, E.: Hole-filled SRTM for the globe Version 4, available from the CGIAR-CSI SRTM 90 m Database, 2008.

Jóhannesson, T., Raymond, C., and Waddington, E.: Time-scale for adjustment of glaciers to changes in mass balance, J. Glaciol., 35, 355-369, 1989.

Kaser, G., Grosshauser, M., and Marzeion, B.: Contribution potential of glaciers to water availability in different climate regimes, Proc. Natl. Acad. Sci. USA, 107, 20223-20227, 2010.

Kuhn, M.: The mass balance of very small glaciers, Z. Gletscherkd. Glazialgeol., 31, 171-179, 1995.

Kuhn, M., Markl, G., Kaser, G., Nickus, U., Obleitner, F., and Schneider, H.: Fluctuations of climate and mass balances: different responses of two adjacent glaciers, Z. Gletscherkd. Glazialgeol., 21, 409-416, 1985.

Lambrecht, A. and Kuhn, M.: Glacier changes in the Austrian Alps during the last three decades, derived from the Austrian glacier inventory, Ann. Glaciol., 46, 177-184, 2007.

Larsen, C. F., Motyka, R. J., Arendt, A. A., Echelmeyer, K. A., and Geissler, P. E.: Glacier changes in southeast Alaska and north- west British Columbia and contribution to sea level rise, J. Geophys. Res., 112, F01007, 10.1029/2006JF000586, 2007.

Maisch, M., Wipf, A., Denneler, B., Battaglia, J., and Benz, C.: Die Gletscher der Schweizer Alpen: Gletscherhochstand 1850, Aktuelle Vergletscherung, Gletscherschwundszenarien, vdf Hochschulverlag, Zürich, 2nd Edn., 2000.

Marzeion, B., Jarosch, A. H., and Hofer, M.: Past and future sealevel change from the surface mass balance of glaciers, The Cryosphere, 6, 1295-1322, doi:10.5194/tc-6-1295-2012, 2012.

Melkonian, A. K., Willis, M. J., and Pritchard, M. E.: Satellite-derived volume loss rates and glacier speeds for the Juneau Icefield, Alaska, J. Glaciol., 60, 743-760, doi:10.3189/2014JoG13J181, 2014.

Motyka, R. J., Fahnestock, M., and Truffer, M.: Volume change of Jakobshavn Isbrae, West Greenland: 1985-1997-2007, J. Glaciol., 56, 635-646, 2010.

Müller, F., Caflish, T., and Müller, G.: Firn und Eis der Schweizer Alpen: Gletscherinventar, No. 57, Geographisches Institut der ETH Zürich, Zürich, 1976.

Nuth, C. and Kääb, A.: Co-registration and bias corrections of satellite elevation data sets for quantifying glacier thickness change, The Cryosphere, 5, 271-290, doi:10.5194/tc-5-271-2011, 2011.

Nuth, C., Moholdt, G., Kohler, J., Hagen, J. O., and Kääb, A.: Svalbard glacier elevation changes and contribution to sea level rise, J. Geophys. Res., 115, F01008, doi:10.1029/2008JF001223, 2010.

Oerlemans, J.: The microclimate of valley glaciers, Igitur, Utrecht University, Utrecht, 2010.

Oerlemans, J. and Reichert, B. K.: Relating glacier mass balance to meteorological data using a Seasonal Sensitivity Characteristic (SSC), J. Glaciol., 46, 1-6, 2000.

Oerlemans, J., Giesen, R. H., and van den Broeke, M. R.: Retreating alpine glaciers: increased melt rates due to accumulation of dust (Vadret da Morteratsch, Switzerland), J. Glaciol., 55, 729-736, 2009.

Paul, F.: The new Swiss glacier inventory 2000: Application of remote sensing and GIS, PhD thesis, Department of Geography, University of Zurich, Zurich, 2004.

Paul, F.: Calculation of glacier elevation changes with SRTM: is there an elevation dependent bias? J. Glaciol., 54, 945-946, 2008.

Paul, F. and Haeberli, W.: Spatial variability of glacier elevation changes in the Swiss Alps obtained from two digital elevation models, Geophys. Res. Lett., 35, L21502, doi:10.1029/2008GL034718, 2008.

Paul, F., Kääb, A., Maisch, M., Kellenberger, T., and Haeberli, W.: Rapid disintegration of Alpine glaciers observed with satellite data, Geophys. Res. Lett., 31, L21402, doi:10.1029/2004GL020816, 2004.

Paul, F., Frey, H., and LeBris, R.: A new glacier inventory for the European Alps from Landsat TM scenes of 2003: challenges and results, Ann. Glaciol., 52, 144-152, 2011.

Radić, V. and Hock, R.: Glaciers in the Earth's hydrological cycle: assessments of glacier mass and runoff changes on global and regional scales, Surv. Geophys., 35, 813-837, doi:10.1007/s10712013-9262-y, 2014.

Rickenbacher, M.: Die digitale Modellierung des Hochgebirges im DHM25 des Bundesamtes für Landestopographie, Wiener Schr. Geogr. Kartogr., 11, 49-55, 1999. 
Rignot, E., Rivera, A., and Casassa, G.: Contribution of the Patagonia Icefields of South America to sea level rise, Science, 302, 434-437, doi:10.1126/science.1087393, 2003.

Rolstad, C., Haug, T., and Denby, B.: Spatially integrated geodetic glacier mass balance and its uncertainty based on geostatistical analysis: application to the western Svartisen ice cap, Norway, J. Glaciol., 55, 666-680, 2009.

Sapiano, J. J., Harrison, W. D., and Echelmeyer, K. A.: Elevation, volume and terminus changes of nine glaciers in North America, J. Glaciol., 44, 119-135, 1998.

Schwitter, M. P. and Raymond, C. F.: Changes in the longitudinal profiles of glaciers during advance and retreat, J. Glaciol., 39, 582-590, 1993.

Shumsky, P. A.: Principles of structural glaciology, Translated from the Russian by D. Kraus, Dover Publications, Inc., New York, 497 pp., 1964.

Sorg, A., Bolch, T., Stoffel, M., Solomina, O., and Beniston, M.: Climate change impacts on glaciers and runoff in Tien Shan (Central Asia), Nat. Clim. Change, 2, 725-731, 2012.

Swiss Federal Office of Topography, swisstopo: DHM25 - Das digitale Höhenmodell der Schweiz, Bundesamt für Landestopographie swisstopo, Wabern, 2000.

Swiss Federal Office of Topography, swisstop: swissALTI ${ }^{3 \mathrm{D}}$, Ausgabebericht 2013, Bundesamt für Landestopographie swisstopo, Wabern, 2013.

Thibert, E., Blanc, R., Vincent, C., and Eckert, N.: Glaciological and volumetric mass-balance measurements: error analysis over 51 years for Glacier de Sarennes, French Alps, J. Glaciol, 54, 522-532, 2008.
Trüssel, B. L., Motyka, R. J., Truffer, M., and Larsen, C. F.: Rapid thinning of lake-calving Yakutat Glacier and the collapse of the Yakutat Icefield, southeast Alaska, USA, J. Glaciol., 59, 149161, 2013.

VanLooy, J. A. and Forster, R. R.: Use of historical elevation data to calculate surface-elevation and volume changes of Ha-Iltzuk Icefield, southwest British Columbia, Canada, 1970 to mid-1980s, Ann. Glaciol., 52, 109-115, 2011.

Vincent, C.: Influence of climate change over the 20th century on four French glacier mass balances, J. Geophys. Res., 107, 4375, doi:10.1029/2001JD000832, 2002.

WGMS (World Glacier Monitoring Service): Fluctuations of Glaciers 2005-2010 (Vol. X), edited by: Zemp, M., Frey, H., Gärtner-Roer, I., Nussbaumer, S. U., Hoelzle, M., Paul, F., and Haeberli, W., ICSU (WDS) / IUGG (IACS) / UNEP / UNESCO / WMO, World Glacier Monitoring Service, Zurich, Switzerland, 336 pp., publication based on database version: doi:10.5904/wgms-fog-2012-11, 2012.

Zemp, M., Paul, F., Hoelzle, M., and Haeberli, W.: Glacier fluctuations in the European Alps 1850-2000: an overview and spatiotemporal analysis of available data, in: The darkening peaks: Glacial retreat in scientific and social context, edited by: Orlove, B., Wiegandt, E., and Luckman, B. H., University of California Press, 152-167, 2008.

Zemp, M., Hoelzle, M., and Haeberli, W.: Six decades of glacier mass-balance observations: a review of the worldwide monitoring network, Ann. Glaciol., 50, 101-111, 2009.

Zemp, M., Thibert, E., Huss, M., Stumm, D., Rolstad Denby, C., Nuth, C., Nussbaumer, S. U., Moholdt, G., Mercer, A., Mayer, C., Joerg, P. C., Jansson, P., Hynek, B., Fischer, A., Escher-Vetter, H., Elvehøy, H., and Andreassen, L. M.: Reanalysing glacier mass balance measurement series, The Cryosphere, 7, 12271245, doi:10.5194/tc-7-1227-2013, 2013. 